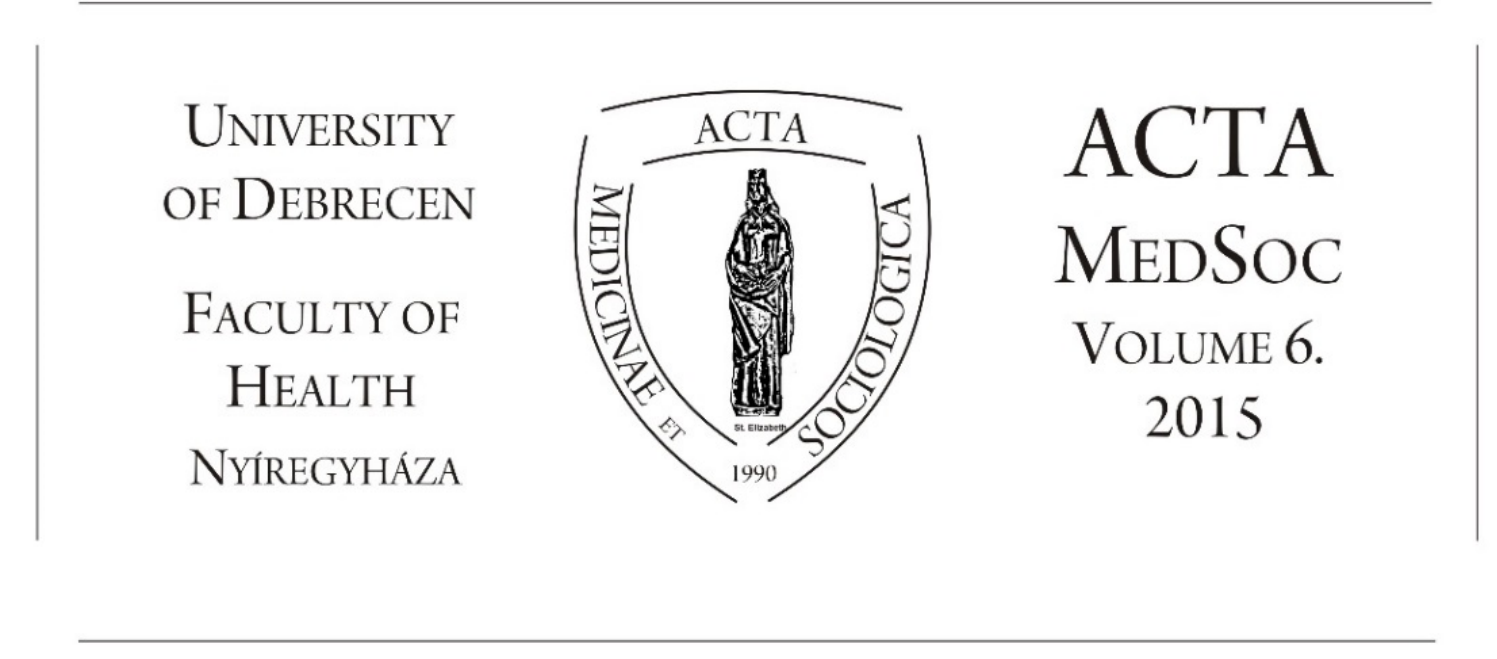

\title{
Mondd meg, kikkel töltöd az idödet, s megmondom, ki vagy. A társas támogatást nyújtó személyes kapcsolati háló néhány jellemzője és müködése a Nyíregyházi járásban
}

\section{Huszti Éva}

Debreceni Egyetem Egészségügyi Kar, Nyíregyháza

\begin{abstract}
Some characteristics and functioning of the social support network on Nyíregyháza district. This present study deals with egocentric social network based on data from Nyíregyháza district. In 2015 we could examined more than 1,500 people's social support system. This paper firstly gives a brief outline of the theory of the contact and the social capitals and then writes about the wideness and composition of egocentric network in the examined district. We study whether there is an essential difference between people who live in Nyíregyháza and in the other, smaller towns. The paper submits examine about strong ties, like close kin and other relatives, friendships; moreover weak ties as neighbours and acquaintances. Dealing with weak ties, this study gives a picture about the contacts which come from belonging to clubs, civil or ecclesiastical organisations and analyses the frequencies of private gathering. Based on theory of Utasi, the paper writes down the four types of micro society integration in Nyíregyháza district.
\end{abstract}

Keywords: egocentric social network, social support, strong ties, weak ties, friendship, solidarity, social integration 


\section{Bevezetés}

A társas kapcsolatok, a társas támogatást nyújtó személyes kapcsolati háló jelentösége

A társas kapcsolatokról szólva elsőként két fogalmat fontos megemlíteni: a kapcsolati tőke és a társadalmi tőke kifejezéseket. A mai modern társadalmakban mindkét tőkeforma jelentős szerepet játszik az emberek mindennapjaiban.

A gazdasági tőke, kulturális töke fogalmai mellett, Pierre Bourdieu nevéhez köthető a társadalmi tőke meghatározása és az is, hogy az említett tôkefajták átalakulhatnak, azaz például gazdasági tőkéből lehet kulturális vagy társadalmi tőkét, vagy például társadalmi tőkéből gazdasági tőkét „kovácsolni” (Bourdieu 1983).

A társadalmi tőke Bourdieu szerint olyan erőforrás, mely egy adott csoporthoz való tartozáson alapul: „, ... az egyén által birtokolt társadalmi tőke nagysága egyrészt azon kapcsolatok hálójának kiterjedtségétöl függ, amelyeket ténylegesen mozgósítani tud, másrészt azon (gazdasági, kulturális vagy szimbolikus) töke nagyságától, amelyet azok birtokolnak, akikkel kapcsolatban áll” (Bourdieu, 1983:168).

A kapcsolati tőke hiánya társadalmi elszigetelődést, izolációt, marginalizációt eredményezhet, csökkenti a társadalmi integráció esélyét (Bourdieu 1983, Granovetter 1982, Sík 2012, Dávid-Huszti-Lukács 2015).

A tanulmányban egy rövid elméleti áttekintés után azzal foglalkozunk, hogy a társas kapcsolatoknak, a személyes kapcsolathálózat kiterjedtségének, összetételének milyen mintázata van a Nyíregyházi járásban, van-e lényegi különbség a nagyvárosban és a kistelepüléseken élők személyes kapcsolathálója között.

\section{Rövid elméleti áttekintés: társadalmi tőke, kapcsolati tőke}

A bevezetőben említett társadalmi tőke jelentőségét ott érhetjük tetten, mikor nagyjából azonos gazdasági és kulturális tőkével rendelkező egyének egymástól lényegesen eltérő eredményeket érnek el attól függően, hogy mennyire képesek saját érdekükben mobilizálni egy csoport rendelkezésre álló tőkéjét (Dávid-HusztiLukács 2015).

A kapcsolati tőke magyarázatához Coleman megközelítését használjuk, aki szerint a kapcsolati tőke a személyek között létrejövő társadalmi intézmény, amely az egyén céljainak elérését segíti úgy, hogy csökkenti a célok eléréséhez szükséges társadalmi költségeket. Coleman a társadalmi tökét kissé másképpen közelíti meg, mint Bourdieu, és olyan erőforrásként értelmezi, mint ami jelentősen hozzájárulhat az egyén iskolai karrierjéhez és ezzel társadalmi mobilitásához is (Coleman 1988).

Nan Lin szerint a kapcsolati tőke az egyén kapcsolathálózati jellemzőit, társas kapcsolatainak minőségét és mennyiségét jelenti, míg a társadalmi tőke a kapcsolatokon keresztül elérhető és mobilizálható erőforrásokat (Lin 2008).

Lin a társadalmi kötődés három formáját különbözteti meg a társas kapcsolatok intenzitása és kölcsönössége szerint: 
1. „binding” - az egyénhez legközelebb álló kapcsolatok, melyek több szempontból is (nem, kor, iskolai végzettség, stb.) inkább homogén jellegüek. Ezek tulajdonképpen a granovetter-i erős kapcsolatok, melyek érzelmeken, kölcsönös segítségnyújtáson alapuló intim és bizalmas kapcsolatok (szülö, gyermek, házastárs, élettárs, bizalmas barát, akikkel az egyén rendszeres és intenzív kapcsolatban áll).

2. „bonding” - az ide tartozók közösen birtokolják az erőforrásokat és az információkat, viszonylag zárt és ugyancsak homogén csoport. Itt már az úgynevezett gyenge kötések is megjelenhetnek.

3. „bridging” - ide a gyenge (de mégis erős, lásd Granovetter: A gyenge kötések ereje címü írását), különböző társadalmi csoportokon átívelő hídszerü kapcsolatok tartoznak. A gyenge kapcsolatok olyan laza ismertségek, melyek mintegy hidat képezve kapcsolják össze az egyéneket tőlük távolabb lévőkkel, akiket az erős kapcsolataik révén egyébként nem tudnának elérni. A társadalmi integráció szempontjából ezek a legfontosabb kapcsolatok. Ide sorolhatók például a szomszédok, ismerösök (Lin 2008, Dávid-HusztiVajda 2015).

1. sz. ábra: A társadalmi töke típusai (Dávid-Huszti-Lukács, 2015)

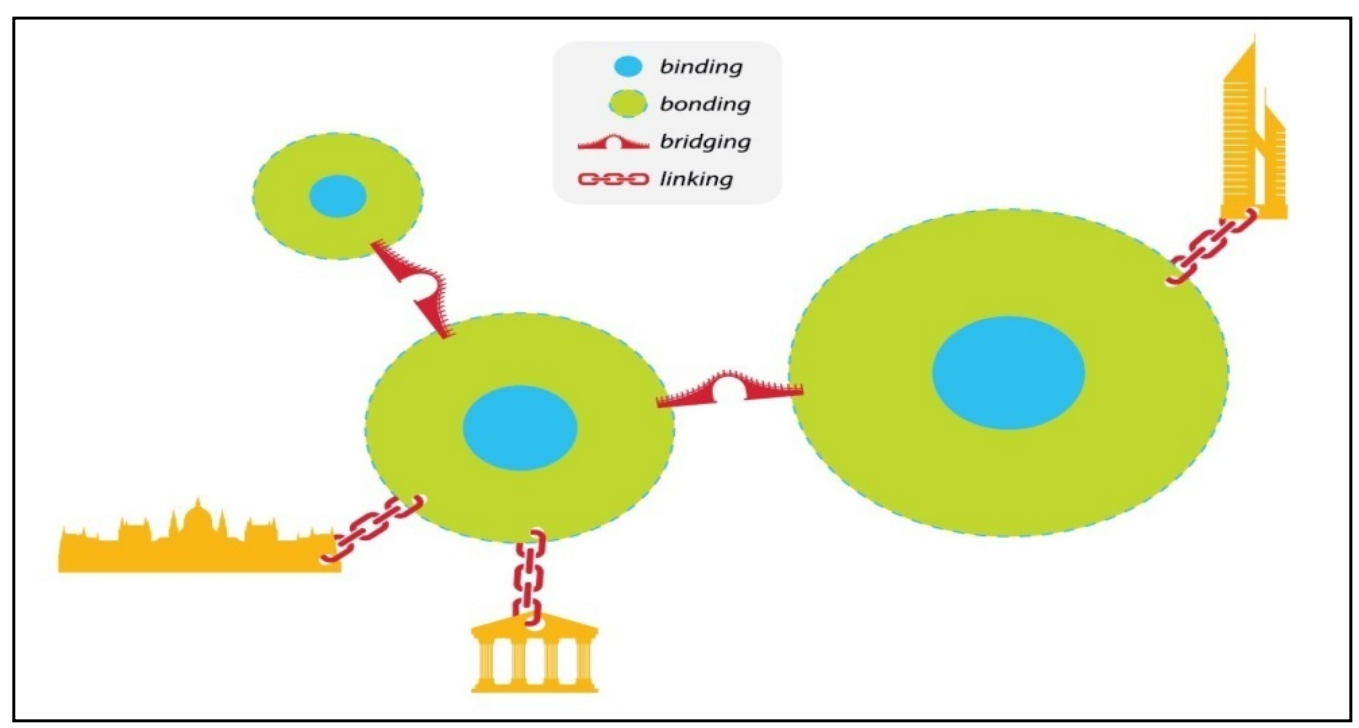

Az erős és gyenge kapcsolatokról összefoglalóan Lin alapján elmondható, hogy: 1. az erős kapcsolatok jelentik az intimitást, bizalmat, támogatást nehéz helyzetekben, továbbá biztosítják a fizikai és pszichés jóllétet, stabilitást és segítik a nehéz helyzetekkel való megküzdést; 2. a gyenge kapcsolatok fontosak a társadalmi csoportok közötti közvetítésben, információáramlásban; összekapcsolják az egyént a sajátjától eltérő társadalmi csoportokkal és alkalmasak arra, hogy áthidalják a társadalmi távolságokat (Dávid-Huszti-Vajda 2015). 


\section{Módszer}

A Nyíregyházi járás személyes kapcsolathálózatát kérdőíves adatfelvétellel vizsgáltuk 2015 tavaszán-nyarán. (Az adatfelvételről és a mintáról az Előszóban lehet bővebben tájékozódni.)

A társas kapcsolathálózatot továbbra is a következő fö dimenziók mentén vizsgáltuk: baráti kapcsolatok mennyiségi és minőségi oldala; társas támogatottság rokoni illetve nem rokoni körben; rokonokkal, barátokkal, szomszédokkal való kapcsolattartás gyakorisága; részvétel a közéletben; magántársasági összejövetelek gyakorisága. A kérdőívben a „Hány barátja van Önnek?” kérdésen kívül bizonyos paraméterek szerint (nem, kor, iskolai végzettség) vizsgáltuk a baráti kapcsolatok homogenitását. A szolidaritási hálót a következő négy dimenzióban mértük: 1. segítségnyújtás hivatalos ügyek intézésében; 2. iskoláztatással kapcsolatban; 3. munkahelykeresésben; 4. valamint betegség esetén jó orvos találásában. Ezekben a kérdésekben a családtagok, rokonok illetve a barátok, ismerősök által nyújtott támogatási formák müködésére voltunk kíváncsiak. Több kérdés mentén vizsgáltuk a közeli és távoli rokonokkal, szomszédokkal, barátokkal való kapcsolattartás gyakoriságát, valamint a megkérdezettek magántársasági összejöveteli szokásait is: milyen gyakran járnak vendégségbe, fogadnak vendégeket, járnak el szórakozni. A vizsgált populáció beágyazottságát a helyi társadalomba a különböző klubokhoz, szervezetekhez való kapcsolódással mértük.

Az egyének kapcsolati hálójának, társas támogatottságuknak mérése nagyvárosi vonatkozásban már a kezdetektől, azaz 2008-tól szerepel a Nyíregyháza Életminősége kutatássorozatban. Kiemelendő, hogy ez a dimenzió meghatározó szerepet játszik a lokális életminőség index (FT index) kialakításában. (Lásd erről bővebben jelen tanulmánykötetben szereplő Takács Péter - Fábián Gergely - Szigeti Fruzsina, 2015) A társas kapcsolatok szerepét különböző dimenziók vizsgálata során is alkalmazzák a kötet szerzői, így a barátok meglétének pozitív hatását a szubjektív egészségérzetre, illetve az egyén szubjektív boldogságérzetére gyakorolt hatását, továbbá a társas kapcsolatrendszer befolyását az idősek életminőségére több, a jelen tanulmánykötetben is olvasható írás részletezi (Hüse, 2015; Patyán, 2015; SzigetiFábián-Takács, 2015).

\section{A társas támogatást nyújtó személyes kapcsolatháló mintázata a Nyíregyházi járásban}

A személyes kapcsolathálót ábrázolhatjuk egy több rétegü hagymával, ahol a „,hagyma” legbelső része az egyén, aki köré különböző típusú, erősségü, funkciójú kapcsolatok épülnek. Az egyénhez legközelebb eső „hagymahéjon” a családtagok, bizalmasok, közeli vagy jó barátok találhatók. Ezt követik azok a már gyengébb kötések, akik még szeretet nyújtanak, a barátok, ismerösök, haverok. A harmadik „hagymahéjon” azok a kapcsolatok vannak, akik a társadalmi integrációt biztosítják: szomszédok, szomszédsági kapcsolatok, civil vagy egyházi szervezetekhez tartozásból eredő kapcsolatok. A negyedik „hagymahéj” olyan kapcsolatokat tartalmaz, akikkel közös az identitás, közös a hovatartozás élménye függetlenül attól, 
hogy az egyén nem áll rendszeres kapcsolatban velük (lokális közösségek, etnikai csoport, stb.) (Dávid-Huszti-Lukács 2015).

Jelen tanulmányban a belső három ,hagymahéjat” vizsgáljuk részletesebben, a nyíregyházi járásban készült adatfelvételből származó adatok alapján.

2. sz. ábra: Személyes kapcsolathálózat felépitése és életminőség/mentálhigiéné összefüggése (Dávid-Huszti-Lukács, 2015)

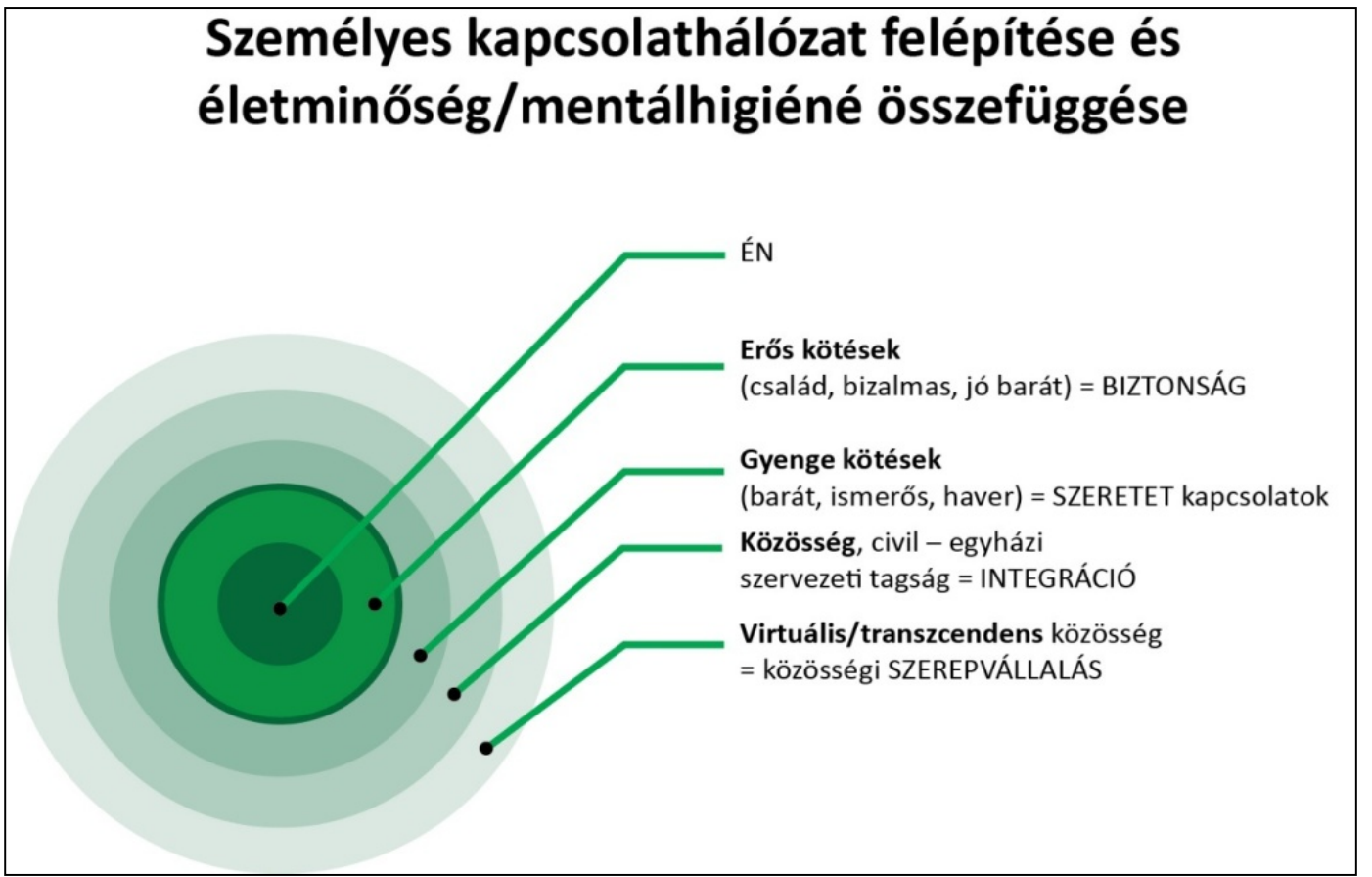

\section{Barátságok}

A barátság fogalmát nehéz meghatározni, mi a kutatás során nem definiáltuk, hogy mit értünk a „barát” szó alatt, leginkább azt fogadtuk el, akit a megkérdezett magában annak tartott. Ezek alapján megállapítható, hogy jelentős különbség van a Nyíregyházán, azaz nagyvárosi környezetben élő felnőttek és a járás egyéb településein élők barátai számát tekintve. A járásban átlagosan négy $(3,7)$ barátot jelöltek meg a megkérdezettek. A városban élök átlagosan öt $(4,7)$ barátot, a járás egyéb településein átlagosan három $(2,9)$ barátot említettek a megkérdezettek. Ami a városi adatot illeti, nincs változás az előző mérésekhez viszonyítva, így elmarad a 2011-ben mért országos átlagtól (5,5 barát) (Omnibusz, 2011). Mind a városban, mind a járás többi településén a férfiaknak valamivel több barátjuk van (város 5 vs. 4,5 illetve 3,3 vs. 2,7), de az eltérés nem jelentős. 
3. sz. ábra „Hány barátja van Önnek?”

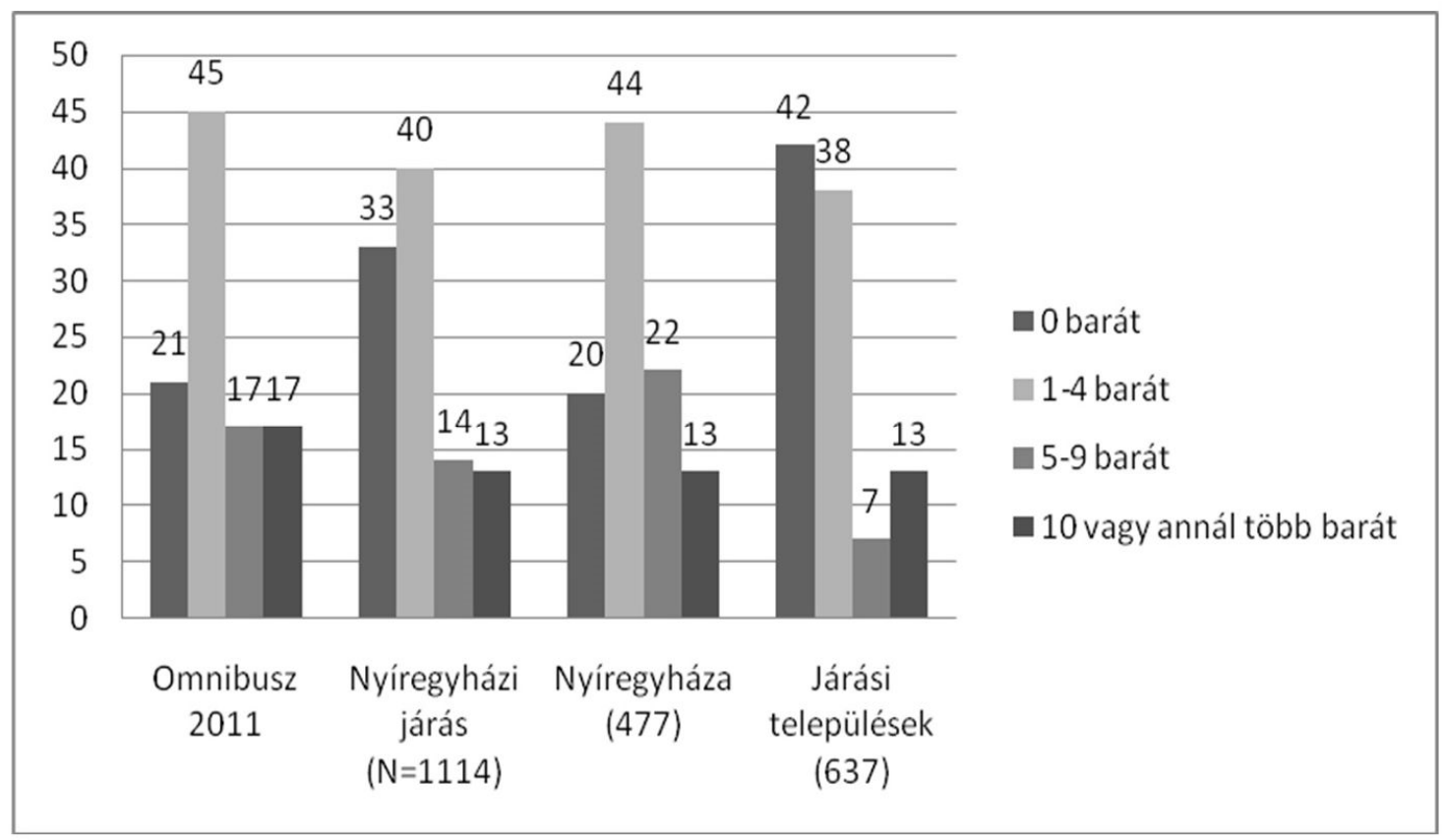

Forrás: Nyíregyháza Életminősége 2015

Az átlagos barátszámot elemezve rögtön kitünik, hogy a járásban jóval magasabb azok aránya (országosan $21 \%$, a járásban $33 \%$ ), akik nem rendelkeznek baráttal. Ha szétbontjuk a vizsgált populációt Nyíregyháza városra és a járás többi településére, világossá válik, hogy a magas arányt a járási települések produkálják: míg Nyíregyházán a baráttal nem rendelkezők aránya megegyezik az országos adattal, a járás egyéb településein kiugróan magas azok aránya, akik azt mondták, hogy egyetlen barátjuk sincs (42\%).

\section{Barátok száma korcsoportonként}

Általánosságban elmondható, hogy hazánkban az idősebb népesség a társadalom izolált csoportjaihoz sorolható, azaz, minél idősebb valaki, annál kevesebb barát veszi öt körül. Ez a tendencia érvényesnek látszik mind a járás, mind külön Nyíregyháza, külön a többi település tekintetében. Hangsúlyozni kell azonban azt, hogy vidéken minden korcsoport jelentősen kevesebb barátot említett, így ezeken a településeken az idősek izolációjának veszélye még erősebben fennáll. 
4. sz. ábra: A barátok átlagos száma korcsoportonként

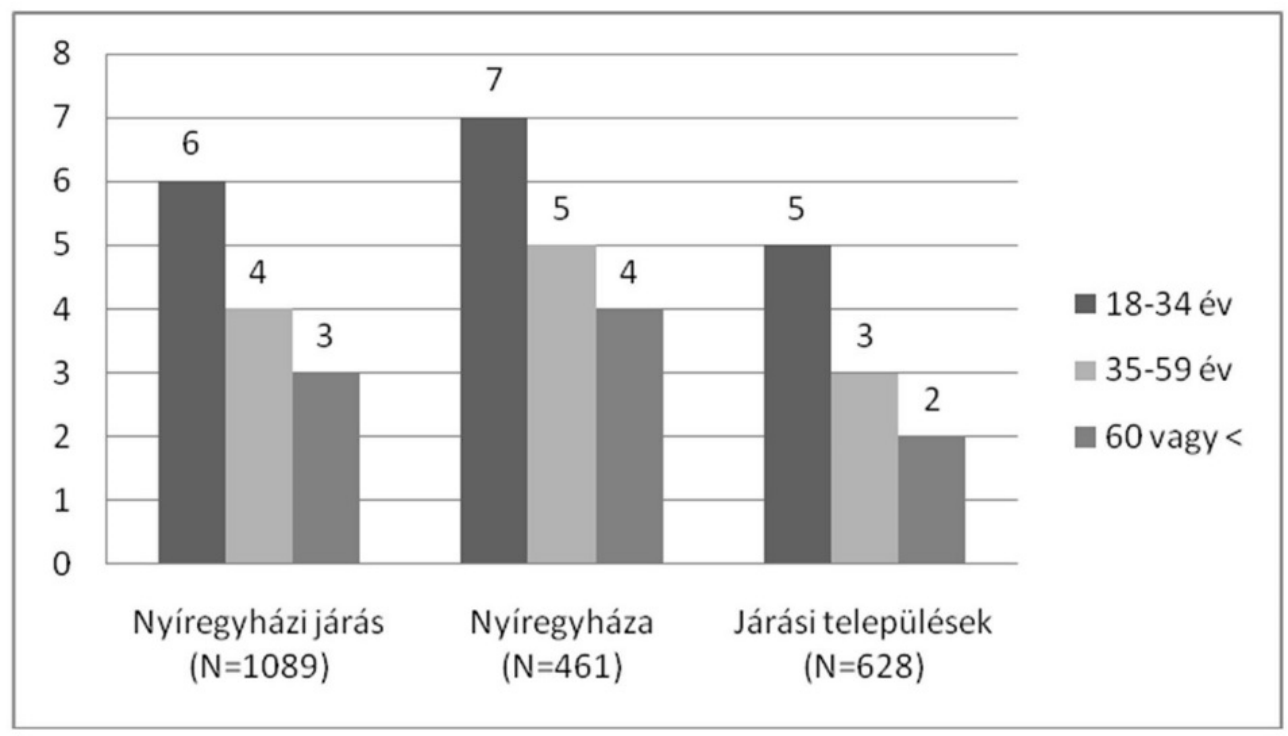

Forrás: Nyíregyháza Életminősége 2015

Barátok száma iskolai végzettség szerint

Minél magasabb valakinek az iskolai végzettsége, annál szélesebb a személyes kapcsolathálózata, annál több gyenge kapcsolat is feltünik benne. Érdemes tehát megvizsgálni, hogy az iskolai végzettség hatása érvényesül-e a járás kis településein is. Nyíregyházán minden eddigi mérés szerint érvényes volt az, hogy a magasabb iskolai végzettséggel rendelkezők átlagosan több barátot említettek. A tendencia továbbra is megmaradt azzal az eltéréssel, hogy az eddigi mérésekhez képest 2015re jelentősen csökkent az alacsonyan kvalifikáltak átlagos barátszáma (2012-ben átlagosan 4,8-ról 2,35-re). A járás többi településére is érvényes az egyenes irányú összefüggés a két vizsgált változó között azzal kiegészítve, hogy az alacsony iskolai végzettséggel rendelkezők izolációjának veszélye még jelentősebb.

5. sz. ábra: A barátok átlagos száma iskolai végzettség szerint

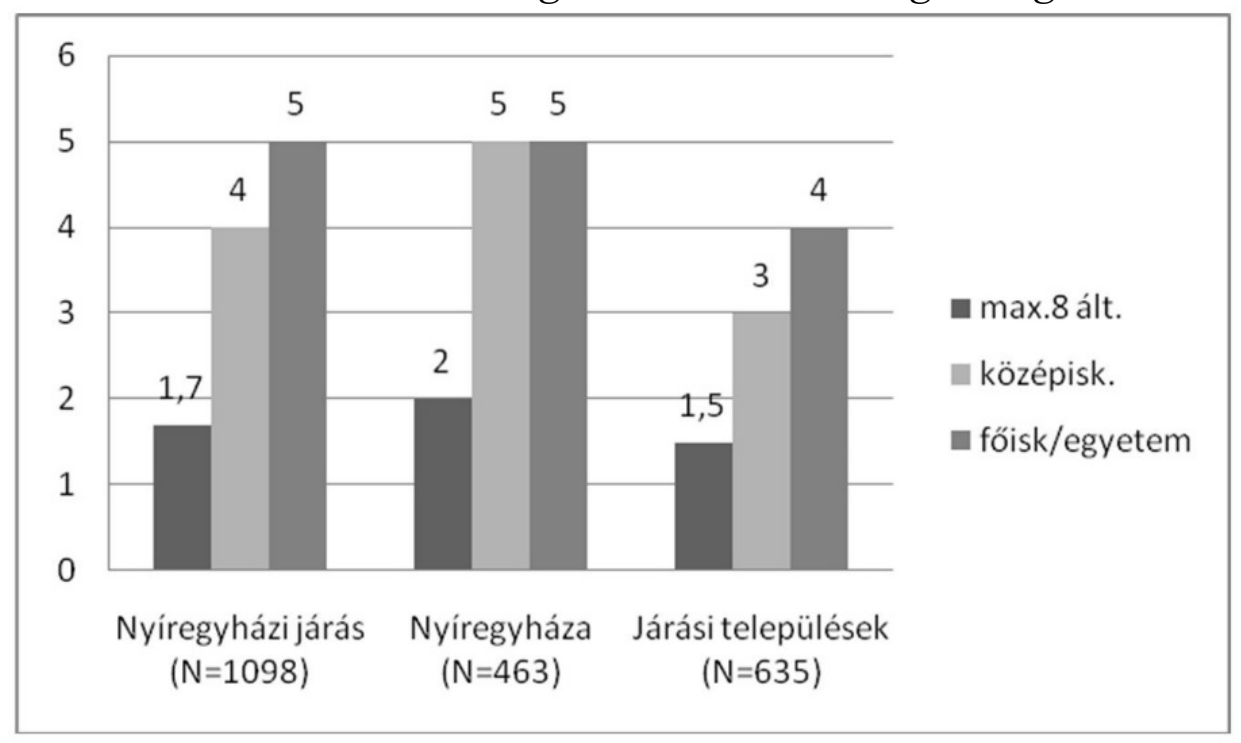

Forrás: Nyíregyháza Életminősége 2015 
Barátok száma és gazdasági aktivitás

A munkaerő-piaci jelenlét, a gazdasági aktivitás döntően befolyásolja azt, hogy milyen a kiterjedtsége és milyen az összetétele a személyes kapcsolathálózatnak. A Nyíregyháza Életminősége vizsgálatok adatai szerint a gazdaságilag aktívak átlagosan eggyel több barátot említettek kérdésünkre, mint azok, akik a kérdezés idején nem dolgoztak. Az eltérés a járás többi településére is érvényes: a munka világába bekapcsolódottak átlagosan kettővel több barátot említettek, mint az inaktívak (4 vs. 2), így a munkaerö-piaci jelenlét a Nyíregyházán kívüli településeken a járásban, még inkább meghatározó a barátok számát illetően.

6. sz. ábra: Barátok átlagos száma a gazdasági aktivitás szerint

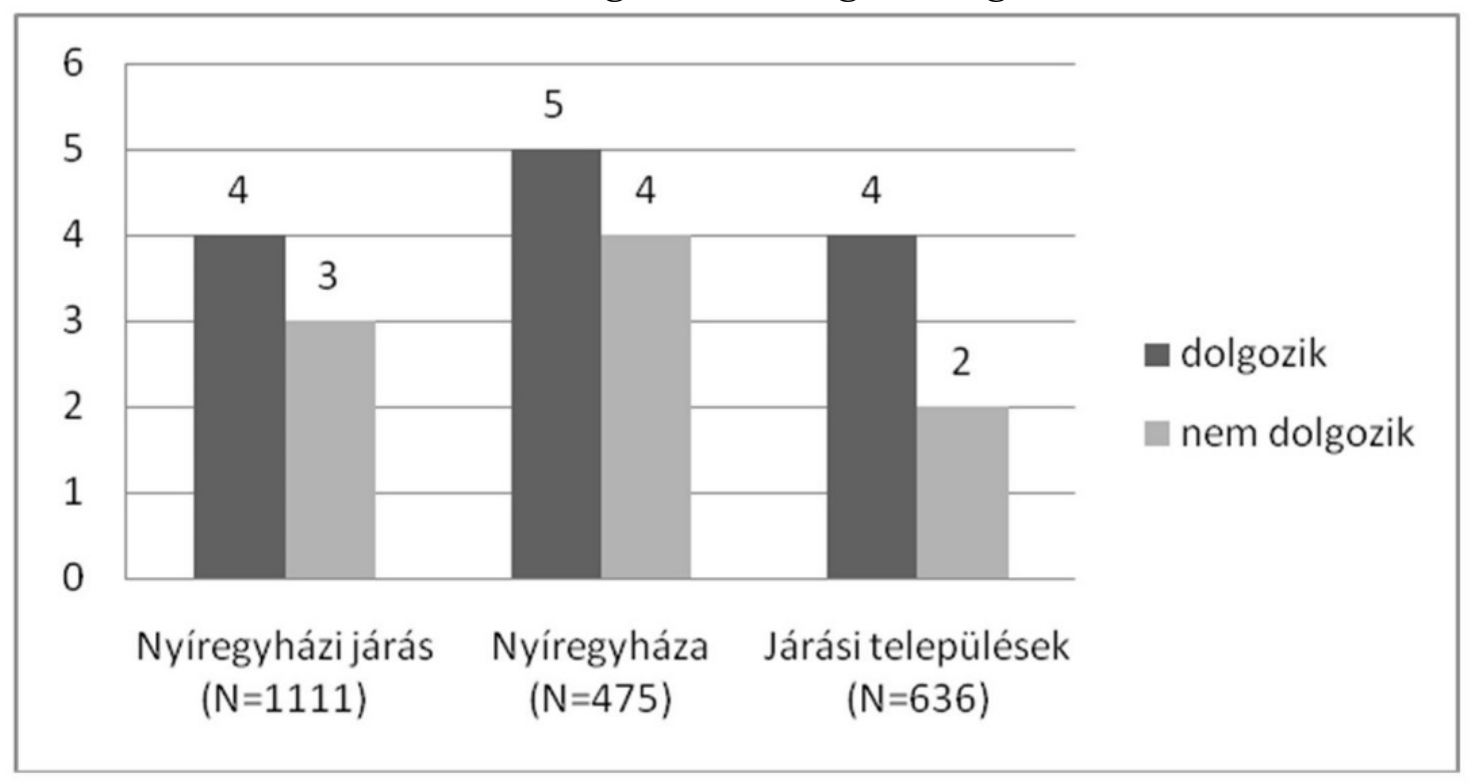

Forrás: Nyíregyháza Életminősége 2015

\section{A társas támogatottság különböző dimenziói}

A modernizáció, az individualizáció, az informatikai újítások térhódítása, de már korábban az iparosodás is olyan elméleteket generáltak, miszerint a modern társadalmakból eltünnek a hagyományos, rokonsági, szomszédsági szolidaritás elemei. Vannak azonban olyan meglátások is, melyek azt állítják, hogy nincs eltünőben a hagyományos szolidaritás, viszont átalakul: a szolidaritás altruista, önzetlenséget elváró jellege csökken, a kölcsönösséget, viszonosságot elváró oldala pedig erösödik (Utasi, 2008).

Néhány korábbi városi vizsgálat vonatkozó eredményei röviden

A természetes védőháló működését, a családtagok, rokonok, barátok, szomszédok, munkatársak által nyújtott támogatásokat Nyíregyházán már korábban is tanulmányozták. Fábián a kilencvenes évek közepén azt vizsgálta, hogy létezik-e a városban természetes védőháló az emberek életében, és azt tudják-e mozgósítani szükség esetén, továbbá arra is kíváncsi volt, hogy mely társadalmi rétegek esetében nem müködnek ezek a rendszerek. A hangsúly azon volt, hogy a természetes 
védőháló hiányát hogyan, milyen szolgáltatások szervezésével lehet kiegészíteni, esetenként helyettesíteni (Fábián, 1997). Ugyancsak Nyíregyházán vizsgálódva Nyírcsák már korábban rámutatott arra, hogy az alacsonyabb társadalmi rétegekhez tartozók gyengébb kapcsolatrendszerrel bírnak, mint azok, akik jobb helyzetben élnek. Ugyanakkor, éppen azok maradnak ki az egyébként meglévő erőforrások eléréséből, akik leginkább rászorulnának arra (Nyírcsák, 1999).

A Nyíregyháza Életminősége kutatássorozatban is külön vizsgáljuk a felnőtt népesség támogató rendszerét a szociális jellegü problémák kapcsán. A BaloghFábián szerzőpáros legutóbbi elemzésükben arra mutatottak rá, hogy a megkérdezettek a természetes védőhálójuk tagjait egyre növekvőbb mértékben veszik igénybe és jóval később kerülnek sorra a mesterséges támogató rendszer által nyújtott szolgáltatások (Balogh-Fábián, 2012).

Társas támogatottság a Nyíregyházi járásban 2015-ben

A következő részben a fentebb említett „hagyma” ábra második és harmadik rétegét vizsgáljuk tovább. Négy kérdés mentén azt elemezzük, hogy van-e a megkérdezetteknek családtagja, rokona, illetve barátja, ismerőse, aki segítséget nyújthat bizonyos helyzetekben.

1. sz. táblázat: Társas támogatottság a Nyíregyházi járásban 2015

\begin{tabular}{|l|c|c|c|c|c|c|}
\hline \multirow{2}{*}{$\begin{array}{l}\text { „Van-e Önnan } \\
\text { olyaládtagja, } \\
\text { rokona/barátja, } \\
\text { ismeröse, aki... }\end{array}$} & \multicolumn{3}{|c|}{ Családtagja, rokona van (\%) } & \multicolumn{3}{|c|}{ Barátja, ismeröse van (\%) } \\
\cline { 2 - 7 } & $\begin{array}{c}\text { Nyír- } \\
\text { egyháza járás } \\
\text { többi } \\
\text { települése }\end{array}$ & Járás & $\begin{array}{c}\text { Nyír- } \\
\text { egyháza }\end{array}$ & $\begin{array}{c}\text { A járás } \\
\text { többi } \\
\text { települése }\end{array}$ \\
\hline $\begin{array}{l}\text { segítséget nyújt } \\
\text { vagy nyújtott } \\
\text { Önnek hivatalos } \\
\text { ügyintézéshez? }\end{array}$ & 52 & 51 & 53 & 31 & 35 & 27,5 \\
\hline $\begin{array}{l}\text { segítséget } \\
\text { nyújtott } \\
\text { iskoláztatással, } \\
\text { továbbtanulással } \\
\text { kapcsolatban? }\end{array}$ & 22 & 28 & 17 & 14 & 20 & 10 \\
\hline $\begin{array}{l}\text { segítséget } \\
\text { nyújt/nyújtott } \\
\text { egy jó állás, } \\
\text { munkahely } \\
\text { megszerzéséhez? }\end{array}$ & 24 & 27 & 21 & 29 & 32 & 26 \\
\hline $\begin{array}{l}\text { betegség esetén } \\
\text { segít/segített jó } \\
\text { orvost szerezni? }\end{array}$ & 43 & 43 & 43 & 31 & 33 & 29 \\
\hline
\end{tabular}

Forrás: Nyíregyháza Életminősége 2015 
Segitségnyújtás hivatalos ügyek intézésében

Családtagok, rokonok. Az adatok alapján elmondható, hogy a járásban élők fele rendelkezik olyan családi, rokoni kapcsolatokkal, akik hivatalos ügyek intézésében (pl. önkormányzati engedélyek, kölcsönök, hitelek, szerződéskötések, stb.) segítséget tudnak nyújtani. Ebben a kérdésben nincs jelentős eltérés a Nyíregyházán és a járás többi településén élők között. Érdemes megjegyezni, hogy Nyíregyházán a legutóbbi méréskor (2012) 55\% volt azok aránya, akik azt mondták, hogy van olyan rokoni kapcsolatuk, akik segíthetnek ilyen esetekben, tehát a társas támogatottság ezen szegmense 2015-re csökkent.

Barátok, ismerösök. A különböző ügyek intézésében nem csupán rokonaink, de barátaink, ismerőseink segítségét is kérhetjük abban az esetben, ha kapcsolati hálónk eléggé kiterjedt, azaz az erős kötéseken kívül megtalálhatók bent és aktivizálhatók a gyenge kapcsolataink is. Az adatok szerint a hivatalos ügyek intézésében a járásban élők inkább családtagjaikat, rokonaikat tudják mozgósítani. A barátok, ismerösök aránya ebben a kérdésben jelentősen elmarad a rokoni támogatottság arányától $(52 \%$ vs. 31\%). Viszont még így is jelentősen felülmúlja a 2008-as országos arányt (15\%). A Nyíregyháza és a járás többi települései közötti különbség valószínúleg a korábban említett alacsony átlagos barátszámtól is függ, bár az eltérés itt nem mutatkozik annyira erősnek. Az ismerősi kör, azok, akiket ismernek, de nem vallanak barátaiknak, valószínüleg tágasabb lehet a járás településein. Nyíregyházán visszaesés mutatkozik a 2012-ben mért arányhoz képest (42\% vs. 35\%).

\section{Segítségnyújtás iskoláztatással, továbbtanulással kapcsolatban}

Családtagok, rokonok. A közeli és távolabbi hozzátartozók segítségnyújtása az iskoláztatással, oktatással kapcsolatban (pl. bejuttatni egyetemre vagy jó szakmát nyújtó iskolába) már szerényebb: járási szinten a minden ötödik megkérdezett mondta azt, hogy neki van olyan családtagja, rokona, akitől segítséget kaphat ilyen esetben. Nyíregyháza és a járás többi települése között azonban itt már jelentős a különbség: míg Nyíregyházán a megkérdezettek 28\%-a mondta azt, hogy neki van olyan hozzátartozója, aki tud segíteni ilyen ügyekben, a járás többi településén csak $17 \%$ volt azok aránya, akik igennel válaszoltak erre a kérdésre. Nyíregyházán a 2012-ben mért adatokhoz képest (22\%), nött azok aránya, akik a rokoni kapcsolataikból eredő kapcsolati tőkéjüket a kulturális tőke (iskoláztatás) növelésére tudják felhasználni.

Barátok, ismerősök. A járásban megkérdezettek 14\%-a számíthat nem rokoni kapcsolataira iskoláztatással, továbbtanulással kapcsolatban. Nyíregyháza és a járás többi települése között jelentős eltérés van ebben a kérdésben: a nyíregyháziak 20\%a mondta, hogy neki van olyan baráti, ismerösi kapcsolata, aki tud segítséget adni, míg a járás egyéb településén csupán $10 \%$ ez az arány. A személyes kapcsolati háló kiterjedtsége, a gyenge kötések előfordulásának valószínűsége alacsonyabb a kisebb településeken, hiányoznak azok a híd-szerü kötések, melyek éppen az ilyen jellegü információ és összeköttetés áramlásában nyújthatnak segítséget. Hangsúlyozni kell azonban azt is, hogy a Nyíregyházára jellemzö 20\%-os arány ebben a kérdésben 
2008 óta nem mutat elmozdulást, tehát a városban is stagnál azok aránya, akik gyenge kapcsolataik révén ilyen erőforrásokat tudnak mozgatni.

Segítségnyújtás egy jó állás, munkahely megszerzésében

Családtagok, rokonok. A járásban $24 \%$ azok aránya, akik közeli és távolabbi rokonaik segítségére számíthatnak egy jó állás vagy munkahely megszerzésében. Nyíregyházán ez az arány 27\%, míg a járás többi településén $21 \%$. Ezek az arányok jóval meghaladják a 2008-ban mért országos arányt, mely szerint jó állás megszerzéséhez általában minden tizedik ember számíthat rokonai segítségére (HÉV, 2008).

Barátok, ismerősök. A granovetter-i gyenge kötések ereje tétel szerint az álláskeresésnél jellemzően a távolabbi, gyenge kapcsolatainkat tudjuk hatékonyan felhasználni, nagyobb valószínüséggel jut el hozzánk a gyenge kapcsolataink segítségével olyan információ, amit munkahely keresésénél hasznosítani tudunk, mint az egyébként népesebb, viszont homogén összetételü erős kapcsolatainkon keresztül (Granovetter, 1973, 1974). Ennek ismeretében pozitívumként említhető, hogy a járásban viszonylag magas azok aránya (29\%), akik munkahelykeresésnél számíthatnak barátaik, ismerőseik segítségére. Magasabb, mint akik családtagjaik, rokonaik támogatását élvezik ebben a kérdésben (24\%). Meg kell jegyezni azonban, hogy a Nyíregyházán élők nagyobb arányban tudják kiaknázni a barátok, ismerősök által nyújtott információkat, mint a járás többi településén élők (32 vs. 26\%), és a városban a 2012-ben mérthez képest is némiképp nőtt a barátok, ismerösök támogatása (30-ról 32\%-ra). A baráti kapcsolatok meglétének jelentősége, illetve annak hiánya a járás kisebb településein ebben a kérdésben is tetten érhető.

Segitségnyújtás betegség esetén (jó orvos)

Családtagok, rokonok. A közeli és távolabbi rokonok segítségnyújtása egy jó orvos szerzésében, a járásban nem mutat lényeges különbségeket: a járás egészére jellemző, hogy a megkérdezettek 43\%-a számíthat ilyen esetben rokonaira. Meg kell jegyezni, hogy a Nyíregyházán mért 2012-es arányhoz képest (60\%) jelentősen csökkent azok aránya, akik jó orvossal való kapcsolathoz számíthat rokonai támogatására.

Barátok, ismerősök. A járásban élők 31\%-a számíthat betegség esetén barátaitól, ismerőseitől származó információra, összeköttetésre jó orvos találásában. Nyíregyháza és a járás egyéb települései között nincs lényeges különbség ebben a kérdésben, bár a nagyvárosban élők kicsivel magasabb arányban számoltak be ilyen jellegü támogató kapcsolatról, mint a járás egyéb településein lakók (33 vs. 29\%). Lényeges változás azonban Nyíregyházán, hogy a korábban mért arányokhoz képest a rokoni kapcsolatok csökkenése mellett a barátok, ismerösök támogatása is jelentősen visszaesett ebben a kérdésben (42,5\%-ról 33\%-ra).

\section{Kapcsolattartás rokonokkal, barátokkal, szomszédokkal}

Tovább vizsgálva az egyént körülvevő „hagymahéjakat”, a biztonságot, szeretetet és az integrációt nyújtó kapcsolatok közül a rokonokkal, barátokkal, szomszédokkal 
való kapcsolattartás gyakoriságát mutatjuk be. Kutatásunkban a családi kapcsolatok közül mind a közeli családtagokkal (szülők, gyermek(ek), testvér(ek)), mind a távolabbi rokonokkal való kapcsolattartás gyakoriságát mértük. A nem rokoni kapcsolatok közül a barátokkal, illetve a szomszédokkal való kapcsolattartást vizsgáltuk.

Fontos itt utalni a kötet egy másik tanulmányára, melyben a szerző a 2011-es népszámlálásai adatok alapján részletesen leírja többek között a járásra jellemző családszerkezeti jellemzőket, változásokat is. A szerző az adatok alapján rámutat arra, hogy a járásban az utóbbi évtizedben növekedett a háztartások száma, mely azok méretének szükülésével is járt, azaz több háztartás lett ugyan, de azok mérete egyre kisebb. Ennek oka lehet a szingli életforma egyre elterjedtebbé válása, az egyszülős családmodell magas aránya, a házasságkötések csökkenő száma (Malakucziné, 2015). A legkisebb és legfontosabb társas közeg, az elsődleges szocializációs terep tehát egyre kisebb, ezzel a segítő, különböző erőforrások áramlásában szerepet játszó családtagok száma is egyre szükül.

Krízishelyzetben, az életbevágóan fontos problémáknál egyértelmủen a biztonságot nyújtó családi kötelék az, amely a legfontosabb. Ezen kapcsolatok előnyei, hogy bizonyos normák által biztosítottak, könnyen mozgósíthatók, mobilizálhatók és irányíthatók. A családi köteléken belül beszélhetünk közeli és távoli családtagokról, rokonokról. Azért fontos különbséget tenni közöttük, mert nem ugyanaz az elvárás a közeli, mint a távoli családtagok, rokonok esetében. A tágabb rokonság szerepe például elhanyagolható a rutinszerü vagy akár a hirtelen fellépő problémák megoldásánál; emocionálisan és instrumentálisan is kevéssé számítunk rájuk. A szük családi kapcsolatokon kívül, a társadalmi integráció, a szolidaritás tekintetében fontos szerepe van a családon kívüli, nem rokoni kapcsolatoknak is. Több kutatás is megerősítette azt az állítást, hogy ha nincs intenzív családtag az ember közvetlen környezetében, akire számíthat, akkor a barát lesz az, akitől a társas támogatást megkaphatja. A baráti kapcsolatok alapvetően önkéntes alapú kapcsolatok, nem úgy, mint a rokonokkal vagy akár a szomszédokkal való kapcsolat, melyek kevésbé nevezhetők önkéntes alapon szerveződőnek. A szomszédok általában társaságot és kisebb szolgáltatásokat biztosítanak, és fontos szerepük van a közösségnyújtásban, így a társadalmi integrációban is (Szabó, 2005; Huszti 2012). 


\section{7. sz. ábra: A rokoni és a nem rokoni kapcsolatokkal való} találkozás/beszélgetés gyakorisága

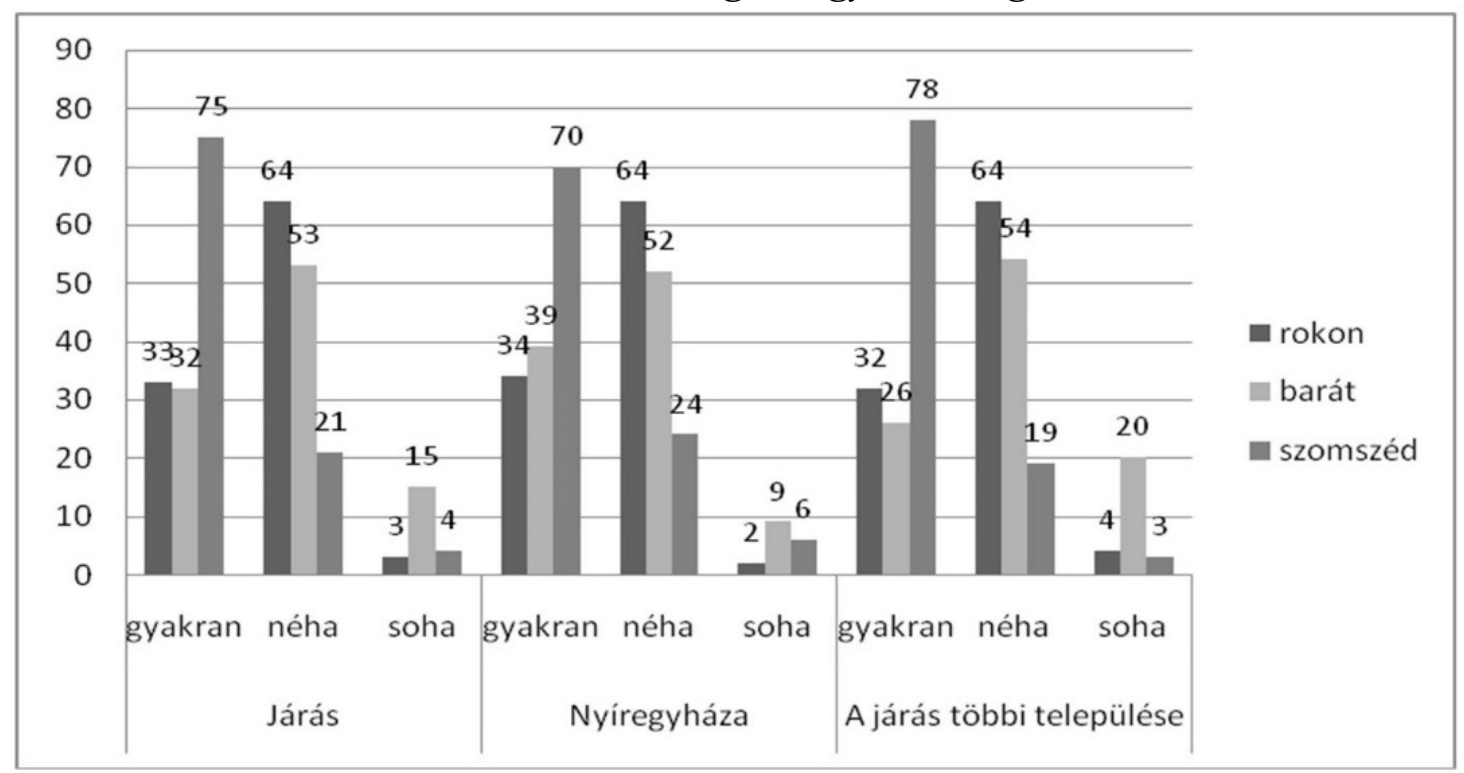

Forrás: Nyíregyháza Életminősége 2015

A rokonokkal, barátokkal való kapcsolattartást a „Milyen gyakran találkozik rokonaival/barátaival?” kérdésekkel mértük, melyre a mindennapos találkozástól az egyáltalán nem találkozásig (soha) jelölhették a megkérdezettek a válaszukat. Gyakori találkozásnak számítottuk a naponta és a hetente egy-két alkalommal történő találkozást. Akik havonta egy-két alkalommal, vagy ritkábban, mint havonta találkoznak rokonaikkal, a „néha” kategóriába kerültek. A szomszédok esetében nem a találkozás, hanem a beszélgetés gyakoriságát kérdeztük. A válaszlehetőségek és a kialakított kategóriák ugyanazok, mint az előző két kérdésnél.

Járási szinten megfigyelhető, hogy a megkérdezettek harmada gyakran találkozik rokonaival. Nincs lényeges eltérés a rokonokkal való kapcsolattartás gyakoriságát tekintve Nyíregyháza és a járás egyéb településein élők között.

A barátokkal való kapcsolattartás esetén már más a helyzet: a járásra jellemző, hogy a megkérdezettek harmada gyakran találkozik barátaival, viszont ez eltér a nagyvárosban és a járás többi településén vizsgálva. A barátokkal való kapcsolattartás gyakorisága magasabb a városban (39 vs. 26\%), illetve, azok aránya, akik soha nem találkoznak barátaikkal, a járás többi településén lényegesen magasabb, mint Nyíregyházán (20\% vs. 9\%).

A szomszédok szerepe és a velük való beszélgetés gyakorisága vitathatatlan: a járásban élők háromnegyede naponta, de legalább hetente több alkalommal is beszélget szomszédjaival. A járás egyéb településein élök nagyobb arányára jellemző, hogy a fizikailag közel lévő, és ebben sok támogatási lehetőséget rejtő szomszédokkal gyakran beszélgetnek $(78 \%)$. A nagyvárosra is jellemző a szomszédokkal való gyakori beszélgetés (70\%), de itt az arány már 2012 óta változatlan, illetve az első méréshez képest (2008) csökkent is. Egy másik kérdés mentén meg tudtuk nézni azt is, hogy a szomszédjai közül hány embert tart 
barátjának a megkérdezett: mind Nyíregyházán, mind a járás többi településén átlagosan egy szomszédot jelöltek meg a megkérdezettek, akik barátok is egyben. Itt a barátság definíciója, annak nehézsége is szerepet játszhat, de szó lehet a szomszédi és baráti kapcsolatoknak tulajdonított eltérő funkcióknak is. Egy következő kutatás során érdemes lehet megvizsgálni az igen magas beszélgetési gyakoriságot mutató szomszédi kapcsolatok tartalmát, funkcióját is a szomszédsági kötelékek, lakóközösségek fejlesztése, a lokális, helyben lévő kapcsolatok hatékonyabb kiaknázása céljából (időseknek házi segítségnyújtás, kisgyermek felügyelet, stb.).

\section{Magántársasági összejövetelek}

A magántársasági összejöveteleknek három aspektusát vizsgáltuk: milyen gyakran mennek vendégségbe, látogatóba a megkérdezettek; milyen gyakran fogadnak vendégeket, látogatókat; milyen gyakran találkoznak barátaikkal, ismerőseikkel presszóban, sörözőben, étteremben vagy más nyilvános helyen.

Ahhoz, hogy megértsük, miért is lehet fontos a vendégségbe, szórakozóhelyekre járás, miért lényeges a vendégfogadás, Utasi Ágnes írását idézem:

„A magántársaságok, illetve baráti körök olyan informális kapcsolatkörök, amelyek az élet számos korábbi helyszínén - különbözö közös együttmüködés során - létrejött kapcsolatból (szomszédságból, munkahelyröl, iskolából, véletlen ismertségböl, formális intézményi kapcsolatból stb.) - szervezödhetnek, az ott létrejött kötelékekböl szimpátia, érdek, közös cél vagy csupán a tradíció, megszokás révén kiválogatódnak és bizalmas szolidaritás-körré rendezödnek. ”(Utasi, 2013:68)

Ahogyan azt már korábban is láttuk, a családtagokon, közeli barátokon kívüli kapcsolatok, az ún. gyenge kötések nagyban szolgálják a társadalmi integrációt, mivel hidat képeznek a társadalom kisebb egységei, közösségei között.

\section{8. sz. ábra: Magántársasági összejövetelek}

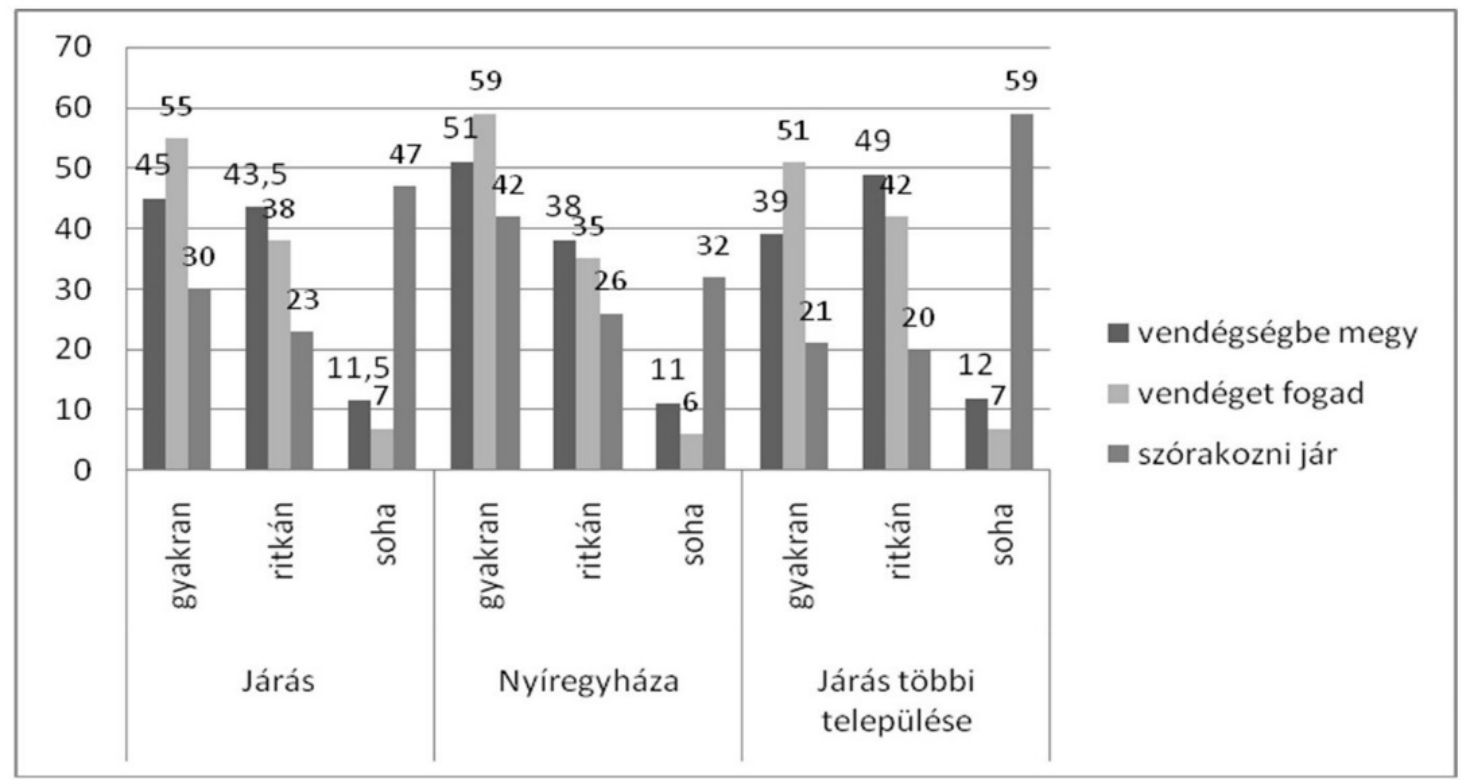

Forrás: Nyíregyháza Életminősége 2015

Gyakorinak számítottuk a hetente vagy havonta történő vendégfogadást, vendégségbe, szórakozni járást. A ritka kategóriába kerültek azok, akik évente 
néhányszor, egyszer-kétszer eljárnak vagy fogadnak vendégeket. Ezek ismeretében azt látjuk, hogy a járási felnőtt népesség 45\%-a mondta azt, hogy gyakran megy vendégségbe, 55\%-uk gyakran fogad vendégeket és 30\%-uk jár el szórakozni hetente vagy havonta. Ha a gyakori magántársasági összejöveteleket vizsgáljuk a két almintán, azaz a nagyvárosban és a járás egyéb településein, szembetűnő különbségekre lehetünk figyelmesek: 1) a nyíregyháziak 51\%-a megy gyakran vendégségbe, míg ez az arány a többi településen alacsonyabb, csupán $39 \%$;) a gyakori vendégfogadás aránya a városban (59\%), a járás egyéb településén $51 \%$; 3 ) a heti, havi szórakozni járás a városban $42 \%$-os, míg a járás más településein csupán 21\%. Itt mutatható ki a legmarkánsabb eltérés. Gondolhatnánk, hogy biztosan a fiatalok gyakori szórakozni járása lehet az ok. A két alminta átlagéletkora azonban azonos, tehát valószínüleg más ok húzódik meg az eltérés mögött. A szórakozási lehetőségek eltérő rendelkezésre állása lehet egy ilyen magyarázó tényező, de ennek további vizsgálatára egy következő kutatás során talán érdemes lenne kitérni. Az érem másik oldala, a magántársasági összejövetelekből való kimaradás, a vendégfogadás, vendégségbe, szórakozni járás elhanyagolása a társadalmi izolációt, dezintegrációt erősítheti. Érdemes megvizsgálni tehát azt is, hogy milyen arányban vannak azok a felnőttek, akik soha nem vesznek részt ilyenfajta szabadidős és személyes kapcsolathálót erösítő tevékenységekben. A járásban élő felnőttek 11,5\%a mondta azt, hogy soha nem megy vendégségbe, 7\%-uk soha nem fogad vendégeket, 47\%-uk pedig soha nem jár szórakozni nyilvános helyekre. Ez utóbbi arány önmagában is nagyon magas, és láthatjuk, e tekintetben milyen jelentős a két alminta közötti eltérés: a nyíregyháziak 32\%-a nem jár el soha szórakozni, a járás egyéb településén élő felnőtt népességnek pedig 59\%-a tartozik ehhez a csoporthoz. A vendégségbe járástól, vendégfogadástól tartózkodók arányában nincs lényeges eltérés a városban és az egyén településeken.

\section{Közélet. Tagság szervezett közösségekben.}

A szervezeti tagság, a klubokhoz való tartozás ugyancsak a társadalmi integráció esélyét növelő társas aktivitások. Akár a civil, akár az egyházi tagság, a kis közösségekbe való rendszeres eljárás növeli annak lehetőségét, hogy a személyes kapcsolati hálónkat mind mennyiségileg feltöltsük, fejlesszük, mind minőségileg formájuk, például megtöltsük gyenge kapcsolatokkal.

A szervezett közösségeket elsősorban az különbözteti meg a fentebb tárgyalt magántársaságoktól, hogy itt már rögzített szabályok, müködési elvek szabhatják meg a közös tevékenységet, együtt töltött időt (Utasi, 2013, Huszti 2014).

Kutatásunkban megkérdeztük, hogy a járás felnőtt lakosságára mennyire jellemző az, hogy helyi közösségeknek, kluboknak, civil vagy egyházi szervezeteknek tagjai. Az adatok alapján az állapítható meg elsődlegesen, hogy a közösségi részvétel meglehetősen szerény: a Nyíregyházi járás felnőtt lakosságának jelentős része, 77\%-a nem tartozik semmilyen közösséghez, szervezethez. Nyíregyházán kicsivel kevesebben (72,5\%), a járás többi településén kicsivel többen (81\%) tartoznak ebbe a körbe. 
A 9. számú ábrán jól látszik, hogy akik mégis tagjai valamilyen szervezetnek, azok hol jelennek meg leggyakrabban. Járási szinten leggyakoribb a különböző vallási közösségekhez való tartozás. Ezen belül is Nyíregyházán nagyobb arányban mondták azt a megkérdezettek, hogy valamilyen vallási közösséghez tartoznak, mint a járás többi településén. A hobby és szabadidős klubokhoz való tartozás a második leggyakoribb azok körében, akik mégiscsak tagjai valamilyen szervezetnek. Lényeges megjegyezni, hogy a Nyíregyházán élők körében kétszer olyan gyakori mint a járás egyéb településein élők körében - az ilyen klubokhoz való tartozás. Ennek kapcsán érdemes lehet megvizsgálni a lehetőségek tárházát (milyen szervezetek milyen lehetőségeket nyújtanak, hol és mikor, stb.) mind a nagyvárosban, mind a kisebb településeken. Akik részt vesznek a közösségi életben, gyakran valamelyik sportklubnak a tagjai. Ebben a kérdésben is érdemes lehet a lehetőségeket és az igényeket részletesen felmérni.

9. sz. ábra: , Tagja-e Ön valamilyen klubnak vagy szervezetnek? (\%)

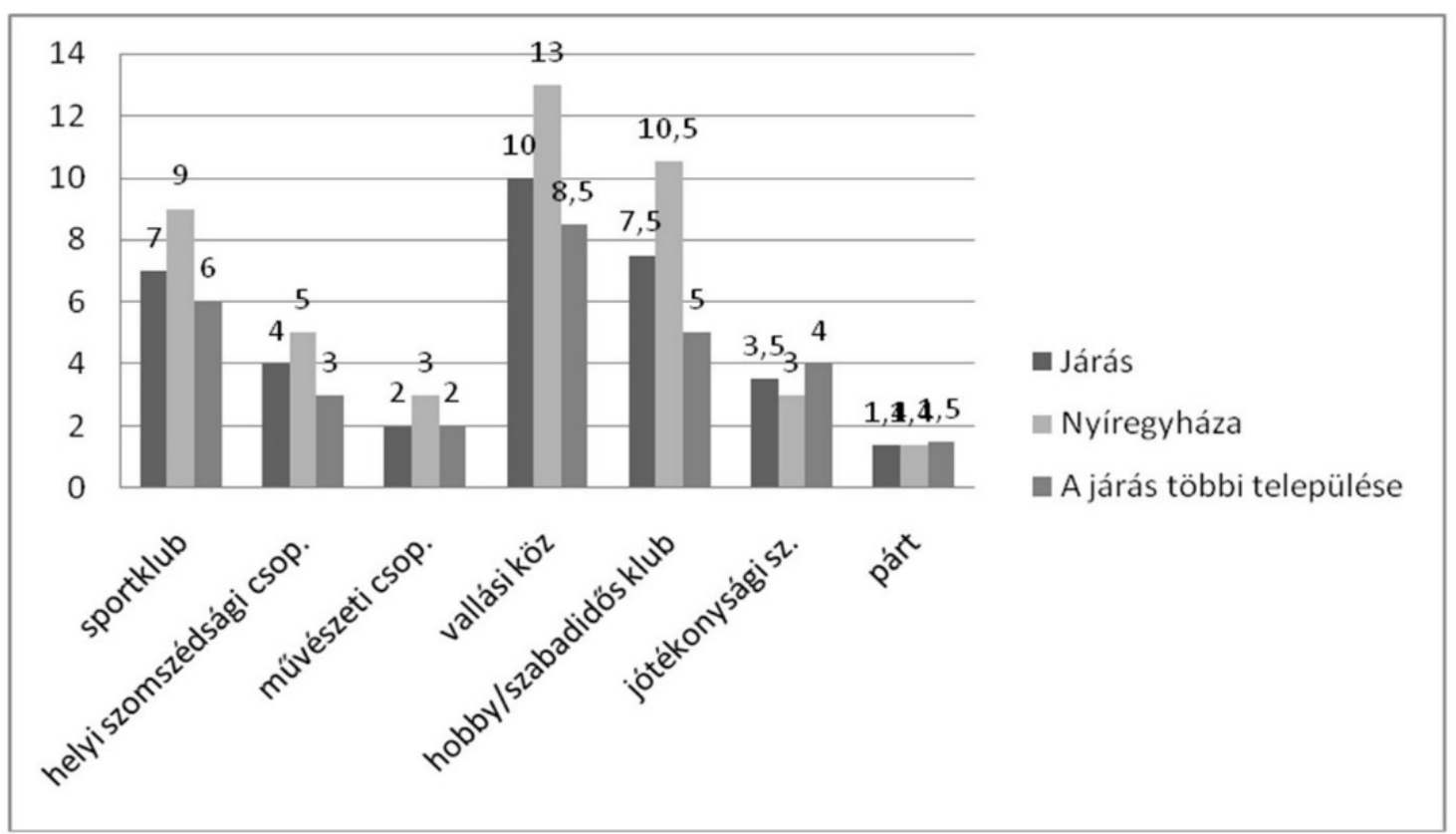

Forrás: Nyíregyháza Életminősége 2015

\section{A szolidaritás kis körei}

Több kutatás is igazolta már, hogy azok az egyének, akik bármilyen társas támogatásban részesülnek, elégedettebbek életkörülményeikkel, boldogabbak, kiegyensúlyozottabbak. A társas támogatás mértéke tehát fontos része a szubjektív életminőségnek (Utasi 2008). „A kapcsolathálózatok biztonságot nyújtanak, lehetővé tesznek bizonyos anyagi forrásokhoz való hozzájutást, szerepet játszanak az egészség, a jólét megörzésében. A társas kapcsolatok a társas támogatás (social support) révén jelentősen hozzájárulnak az egyén jó életminöségéhez. A társadalmi támasz/támogatás az egyik legfontosabb meghatározója annak, hogy az emberek biztonságban érezhetik-e magukat, kiegyensúlyozottnak, optimistának, elégedettnek, boldognak vallják-e magukat" (Utasi, 2006:299). 
Embertársaink felé szolidaritásunkat különböző formában fejezhetjük ki: nyújthatunk egymásnak biztonságot, de hasznos információt is; közbenjárhatunk valahol a másik érdekében; érzelmi támogatást adhatunk azzal, ha meghallgatjuk; társas támogatást nyújtunk, ha elhívjuk magunkhoz vagy elmegyünk együtt valahová, stb. Ami fontos, hogy az egyének közötti szolidaritás kedvezően hat a közösségre, így a mikrotársadalmi integráció kialakulásának, fennmaradásának is nagyobb az esélye. A mikrotársadalmi integráció lényege, hogy az adott közösség ne szakadjon szét, a közösséghez tartozók ne izolálódjanak. A különböző szolidaritásformák eltérőek lehetnek a különböző társadalmi rétegekben, de a közösségi kapcsolatokból fakadó szolidaritás fontos szerepet kap minden csoport esetében (Utasi 2002, Dávid-Huszti-Lukács 2015).

Utasi Ágnes alapján (2002) a mikrotársadalmi integrációnak négy típusát különböztethetjük meg:

1. társadalmilag nagyon erősen beágyazottak (mind a családi, mind a családon kívüli kapcsolatok szerepe jelentős)

2. kiemelkedő rokoni támogatottságot élvezők

3. erős társasági-egyesületi kapcsolatokkal bírók

4. gyengén integrálódók (gyenge a családi és a családon kívüli kapcsolatok szerepe)

A rendelkezésre álló adatok alapján megvizsgáltuk, hogy a négy típus milyen arányban van jelen Nyíregyházán, illetve a járás többi településén, azaz a különböző típusok milyen gyakorisággal fordulnak elő nagyvárosban illetve kisebb településeken. A kérdésben használható változók alapján a következőképpen alkottuk meg a fenti típusokat:

1. társadalmilag nagyon erösen beágyazottak: azokat a megkérdezetteket számoltuk ide, akikre a következő ismérvekből legalább négy jellemző - 1) van legalább egy barátja; 2) van családi/rokoni támogatottsága legalább egy vizsgált dimenzióban; 3) van baráti/ismerösi támogatottsága legalább egy vizsgált dimenzióban; 4) legalább egy klubnak, szervezetnek tagja; 5) gyakran jár magántársaságokba 6) gyakran tartja a kapcsolatot a barátaival vagy rokonaival vagy szomszédjaival.

2. kiemelkedö rokoni támogatottságot élvezök: azokat számoltuk ide, akikre a felsoroltak közül legalább három jellemző érvényes - 1) nincs barátja; 2) van családi/rokoni támogatottsága legalább egy vizsgált dimenzióban; 3) nincs baráti/ismerősi támogatottsága legalább egy vizsgált dimenzióban; 4) egy klubnak, szervezetnek sem tagja; 5) ritkán vagy egyáltalán nem jár magántársaságokba; 6) ritkán vagy egyáltalán nem tartja a kapcsolatot barátaival rokonaival, szomszédjaival.

3. erős társasági-egyesületi kapcsolatokkal bírók: azokat soroltuk ide, akikre legalább három állítás érvényes a következők közül - 1) van legalább egy barátja; 2) van családi/rokoni támogatottsága legalább egy vizsgált dimenzióban; 3) van baráti/ismerősi támogatottsága legalább egy vizsgált dimenzióban; 4) kettő vagy több klubnak, szervezetnek is tagja; 5) gyakran 
jár mindenféle magántársaságokba; 6) gyakran tartja a kapcsolatot barátaival rokonaival, szomszédjaival.

4. gyengén integrálódók: azokat soroltuk ide, akikre legalább három jellemző érvényes a felsoroltak közül - 1) nincs barátja; 2) nincs családi/rokoni támogatottsága egy vizsgált dimenzióban sem; 3) nincs baráti/ismerősi támogatottsága egy vizsgált dimenzióban sem; 4) egy klubnak, szervezetnek sem tagja; 5) ritkán vagy egyáltalán nem jár magántársaságokba; 6) ritkán vagy egyáltalán nem tartja a kapcsolatot barátaival, rokonaival, szomszédjaival.

2. sz. táblázat: A mikrotársadalmi integráció négy típusa a Nyíregyházi járásban 2015

\begin{tabular}{|l|c|c|c|}
\hline \multicolumn{1}{|c|}{ Típusok } & $\begin{array}{c}\text { Járás (N=1663) } \\
\text { (gyakoriság \%) }\end{array}$ & $\begin{array}{c}\text { Nyíregyháza } \\
\text { (gyakoriság } \\
\text { \%) }\end{array}$ & $\begin{array}{c}\text { Járás többi } \\
\text { települése } \\
\text { (gyakoriság \%) }\end{array}$ \\
\hline $\begin{array}{l}\text { Társadalmilag nagyon } \\
\text { erősen beágyazottak }\end{array}$ & 43 & 50 & 36 \\
\hline $\begin{array}{l}\text { Kiemelkedő rokoni } \\
\text { támogatottságot élvezők }\end{array}$ & 47 & 42 & 52 \\
\hline $\begin{array}{l}\text { Erős társasági-egyesületi } \\
\text { kapcsolatokkal bírók }\end{array}$ & 27 & 32 & 23 \\
\hline Gyengén integrálódók & 43 & 38 & 48 \\
\hline
\end{tabular}

A járásra leginkább a kiemelkedő rokoni támogatottság jellemző (47\%), de sokan tartoznak az erősen integrálódott típusba (43\%) is. Ugyancsak gyakori a gyenge társadalmi integráció (43\%). Az erős társasági és egyesületi kapcsolatok kevéssé jellemzőek a járás egészére (27\%), amit elsősorban az alacsony szervezeti, ill. klubtagság magyaráz.

Ha csak Nyíregyházán vizsgáljuk az említett mikrotársadalmi integrációs típusokat, láthatjuk, hogy a nagyvárosi felnőtt népesség, a vizsgált paraméterek alapján, a társadalmilag nagyon erősen beágyazódott típusba sorolható. A városi felnőttek 42\%-a kiemelkedő rokoni támogatottsággal jellemezhető. Az erős társasági-egyesületi kapcsolódás a városban valamivel nagyobb (32\%), mint a járás egészére vetítve, de így is csak minden harmadik nyíregyházi felnőttet lehet ebben a típusban említeni. A gyengén integrálódottak aránya Nyíregyházán 38\%.

A járás többi települését elemezve látható, hogy a legtöbben (52\%) a kiemelkedő rokoni támogatottsággal jellemezhető típusba sorolhatók. Viszont kiemelendő, hogy a gyengén integrálódottak aránya a járás többi településén $48 \%$, azaz minden második felnőttre gyenge társadalmi beágyazottság jellemző kapcsolatait tekintve. Az erős társasági-egyesületi kapcsolatokkal bíró típus jellemző a legritkábban (23\%) a járás kisebb településein. 


\section{Erôs társadalmi beágyazottsággal jellemezhető csoportok}

A városban a férfiak 55, a nők 48\%-a tartozik az 1. típusba. Ez az arány a járás többi településén $41 \%$ a férfiaknál és $34 \%$ a nőknél. (Az összefüggés a járásban szignifikáns, $\mathrm{p}<0,01$.) Mind Nyíregyházán, mind a járás egyéb településén inkább a férfiakra jellemző az erős társadalmi integráció.

A megkérdezett kora és az erős társadalmi beágyazottság szorosan összefügg $(\mathrm{p}<0,001)$ : a városban a 18-34 éves korosztály háromnegyede $(73 \%)$ tartozik ebbe a csoportba. A járás kisebb településein, ugyanezen korosztálynak fele (48\%) sorolható ide. A 35-59 évesek esetében a városiak 47\%-a, a járás többi településen élőknek pedig 36\%-a tekinthető erősen integrálódottnak, azaz sokféle kapcsolattal rendelkezőnek. A városi idősek (60 éves és annál idősebb népesség) 44\%-a, míg a kisebb települések 31\%-a tartozik az erős társadalmi beágyazottsággal jellemezhető csoporthoz.

Iskolai végzettséget tekintve általánosságban megállapítható, hogy minél magasabb valakinek az iskolai végzettsége, annál nagyobb eséllyel tartozik az erősen integrálódó csoportba $(\mathrm{p}<0,05)$. Nyíregyházán a legmagasabb iskolai végzettséggel rendelkezők 69\%-a, a járás többi településének fele $(51 \%$-a) sorolható ide. A maximum nyolc általánossal rendelkezők 31 illetve 23\%-a tartozik ehhez a csoporthoz. A valamilyen középfokú iskolai végzettséggel rendelkező városiak fele (49\%), a járás többi településén pedig 40\%-a tekinthető társadalmilag erősen beágyazottnak.

\section{Kiemelkedő rokoni támogatottsággal jellemezhető csoportok}

A 2. típusban $37 \%$ a férfiak aránya, $44 \%$ a nők aránya a városban, a nőkre inkább jellemző az erős rokoni támogatottság. A járás többi településére is elmondható ez, hiszen $48 \%$ a férfiak és $54 \%$ a nők aránya ebben a csoportban. (Az összefüggés a járásban szignifikáns, $\mathrm{p}<0,05$.)

A megkérdezett kora és a kiemelkedő rokoni támogatottság összefügg $(\mathrm{p}<0,05)$ és a következő mintázatot mutatja: a városi fiatalok (18-34 évesek) harmada (33\%) jellemezhető kiemelkedő rokoni támogatottsággal, míg a járás egyéb településein ez az arány magasabb, 42\%. Nyíregyházán a 35-59 évesek 40\%-a, a járás többi településén fele sorolható ebbe a csoportba. A 60 éves és idősebb népesség fele (49\%) tartozik az erős rokoni támogatottsággal jellemezhető csoportba. Ez az arány a kisebb településeken magasabb, 59\%.

A járás településein, minden vizsgált korosztályban jellemzőbb az erős rokoni támogatottság, mint Nyíregyházán. A rokoni kapcsolatok jelentőségét és az egyéni kapcsolathálózat fontos jellemzőjét mutatja ezt a kisebb településeken.

$A z$ erős rokoni támogatottság, mind a városiak, mind a járás többi településén élő alacsony iskolai végzettséggel bírók körében magas: 61 ill. 62\%. A középfokú végzettséggel rendelkezők 42 illetve 47\%-a sorolható az erős rokoni támogatottsággal jellemezhető csoporthoz. A városban a magasan kvalifikáltak esetén az ide sorolhatóak aránya jelentősen alacsonyabb (34\%), a maximum nyolc általánossal bírókhoz képest, míg a járás többi településén a magas iskolai végzettség kevéssé érezteti hatását, mivel a föiskolai, egyetemi végzettségüek körében is magas, 46\%- 
os az erős rokoni támogatottsággal jellemezhetők köre. Az alacsony iskolai végzettség és a kis települési lakhely jelentősen növel az erős rokoni szálakkal jellemezhető egyéni kapcsolathálózatot. (Az összefüggés szignifikáns, $p<0,001$.)

\section{Erôs társasági-egyesületi jelenléttel jellemezhető}

A városban nincs különbség a nemek között, mind a férfiak, mind a nők 30\%-a sorolható ebbe a típusba. A járás többi településén azonban a férfiakra jobban jellemző az erős társasági-egyesületi jelenlét (27\%), mint a nőkre (21\%). (Az összefüggés a járásban szignifikáns, $\mathrm{p}<0,05$.)

Az erős társasági-egyesületi jelenlét is jelentős összefüggést mutat a vizsgált személy korával $(\mathrm{p}<0,001)$ : a fiatal nyíregyháziak fele $(49 \%)$ sorolható ebbe a csoportba, míg a vidéki fiatalok 36\%-ára jellemző az erős nem rokoni kapcsolathálózat. A városi 35-59 éves korosztály harmada (30\%) tartozik a vizsgált paraméterek alapján ide, míg a járás többi településén az azonos korcsoportba tartozók ötöde (20\%). Az idősebb korosztály (60 éves és annál idősebb) 24\%-a illetve 18\%-a jellemezhető erős társasági-egyesületi jelenléttel városon illetve a többi településen.

$\mathrm{Az}$ általános tendencia az, hogy minél magasabb iskolai végzettséggel rendelkezik valaki, annál nagyobb valószínűséggel vannak egyéni kapcsolathálózatában gyenge kötésü kapcsolatok, annál heterogénebb a kapcsolathálózata. A városban az alacsony iskolai végzettséggel bírók $21 \%$-a tartozik ebbe a csoportba, míg a magasan kvalifikáltak 34\%-a sorolható ide. Ez az arány a járás többi településén $11 \%$ illetve $33 \%$. A magas iskolai végzettség tehát a kisebb településeken nem érezteti hatását, már ami a kapcsolathálózat heterogenitását, a nem rokoni kapcsolatok gyakoriságát illeti. A középiskolai végzettséggel rendelkezők harmada (33\%) illetve 27\%-a tartozik az erős nem rokoni kapcsolatokkal jellemezhetö csoporthoz. $(\mathrm{p}<0,05)$

\section{Gyengén integrálódott társadalmi csoportok}

A városban a férfiak 38 , a nők $40 \%$-a tartozik ebbe a típusba, míg a járás többi településén $45 \%$ a férfiak és $49 \%$ a nők aránya. A járás kisebb településein tehát a nők feléről mondható el, hogy gyenge társadalmi integráció jellemző rá. (Az összefüggés a járásban szignifikáns, $\mathrm{p}=0,00$.)

A gyenge társadalmi integráció és a vizsgált korosztályok között jelentős összefüggés van $(p<0,05)$ : mind a városra, mind a többi településre elmondható, hogy a legkevésbé integrálódott korcsoport a 35-59 évesek. Nyíregyházán a 18-34 évesek 21\%-a, a 35-59 évesek 44\%-a, a 60 évesek és idősebbek 43\%-a sorolható a gyengén integrálódó csoportba. A járás többi településein a vonatkozó arányok: $40 \%, 50 \%$ illetve $45 \%$, azaz a középkorúak fele tartozik ebbe a csoportba a kisebb településeken. Nem elhanyagolható, hogy a járási kis települések fiataljainak jelentős része (40\%-uk) ugyancsak ide sorolható.

A gyengén integrálódott társadalmi csoportban az alacsony iskolai végzettséggel rendelkező nyíregyháziak 45\%-a, illetve a járás többi településén élő felnőtt korúak 56\%-a tartozik a vizsgált paraméterek alapján. A középiskolai papírral bírók esetén 
az ide tartozók aránya 49\% illetve 45\%. A magasan kvalifikált városiak 35\%-a, a járás többi településén élők $36 \%$-a sorolható a gyengén integrálódott csoportba. A magas iskolai végzettség tehát településtől függetlenül érezteti hatását a társadalmi integráció szempontjából: minél képzettebb valaki, annál kevesebb eséllyel kerül ebbe a csoportba.

\section{Összefoglalás}

A tanulmányban a kapcsolati és a társadalmi tőke rövid értelmező áttekintése után azzal foglalkoztunk, hogy a társas kapcsolatoknak, a személyes kapcsolathálózat kiterjedtségének, összetételének milyen mintázata van a Nyíregyházi járásban, vane lényegi különbség a nagyvárosban és a kistelepüléseken élök személyes kapcsolathálója között. A kérdés vizsgálata során a társas támogatást nyújtó személyes kapcsolathálózatnak különböző részleteit vettük górcső alá a Nyíregyházi járásban készült kérdőíves adatfelvételből származó adatok alapján. Ennek során foglalkoztunk az egyénhez legközelebb eső bizalmas kapcsolatokkal, úgymint a közeli családtagok, távolabbi rokonok, közeli vagy jó barátok alkotta kapcsolathálózattal, továbbá a már gyengébb kapcsolatoknak számító barátok, ismerősök által nyújtott társas támogatás gyakoriságával. A gyengébb kötések közül a társadalmi integrációt biztosító szomszédok, szomszédsági kapcsolatok, civil vagy egyházi szervezetekhez tartozásból eredő kapcsolatok kerültek tárgyalásra a járásra vonatkoztatva.

A közeli kapcsolatokról szólva lényeges megemlíteni, hogy a járás kis településein még az erős kapcsolatokhoz számító közeli barátok számát tekintve is lényeges elmaradás figyelhető meg Nyíregyházához viszonyítva is. Az átlagos barátszám a nagyvárosban öt, a járás kisebb településein pedig három. Fontos kiemelni a barátokkal nem rendelkezők arányát: Nyíregyházán a felnőtt lakosság 20 százaléka nem rendelkezik egyetlen baráttal sem, ez az arány a járás többi településén 42 (!) százalék. Az országos adatok szerint a felnőtt népesség 21\%-ának nincs egyetlen barátja sem (TÁRKI Omnibusz, 2011).

A témához tartozik, hogy a járás kisebb településein minden korcsoport jelentősen kevesebb barátot említett, így ezeken a településeken az idősek izolációjának veszélye még erősebben fennáll.

Négy kérdés mentén vizsgáltuk, hogy mennyire számíthatnak családtagjaik, rokonaik, illetve barátaik, ismerőseik támogatására a járásban élő felnőttek. Összefoglalva elmondható, hogy a járásban a családtagok, rokonok támogatása dominál a hivatalos ügyek intézésében, az egészségügyi illetve az oktatási ellátással kapcsolatban, míg a barátok, rokoni támogatása a munkaerő-piaci összeköttetésekben, a jó állás, munkahely megszerzésében jelentős.

A magántársasági összejövetelek gyakoriságát, mint a bizalmas szolidaritás kis köreit vizsgáltuk. Általánosságban elmondható, hogy a társadalmi integrációt biztosító kötések hiányoznak, vagy nagyon kevéssé vannak jelen a járásban élő felnőtt lakosság kapcsolathálózatában. A járásban élők 45\%-a jár el gyakran (legalább havonta) vendégségbe, fele $(55 \%)$ fogad gyakran vendéget, és mintegy 
harmaduk (30\%) jár el legalább havonta szórakozni. Ezek az arányok rendre magasabbak Nyíregyházán és alacsonyabbak a járás többi településén.

A társadalmi integrációt szolgáló másik kapcsolati szegmens, a klubokhoz, szervezetekhez, kisebb közösségekhez való tartozás sem mutat kedvezőbb képet. A közösségi részvétel összességében meglehetősen szerény: a Nyíregyházi járás felnőtt lakosságának jelentős része, 77\%-a nem tartozik semmilyen közösséghez, szervezethez. Nyíregyházán kicsivel kevesebben (72,5\%), a járás többi településén kicsivel többen (81\%) tartoznak ebbe a körbe.

Mindezt azért érdemes hangsúlyozni és felhívni rá a figyelmet, mert a bezáródás, izolálódás veszélye azoknál nagyobb, akiknek ugyan sok erős kapcsolatuk van, de kevés gyenge kötésủ kapcsolattal rendelkeznek. Ezeknek az embereknek a kapcsolati hálójuk a sok erős kötés miatt nagyon sürü, de túlságosan homogén, így az erőforrás nem tud széles körben áramlani, beszükül az a pálya, ahol a különbözö tőkék „közlekedhetnek”. Azok az emberek, akiknek kapcsolathálózatukban több gyenge kapcsolat van, könnyebben jutnak különböző erőforrásokhoz, könnyebben integrálódnak a társadalomba (Granovetter 1973, 1974, Angelusz-Tardos 1998, Gyarmati 2009, Dávid-Huszti-Vajda 2015).

Utasi Ágnes alapján a mikrotársadalmi integrációnak négy típusát különböztettünk meg és ezek gyakoriságát vizsgáltuk a járásban. Ha csak Nyíregyházát nézzük, megállapítható, hogy a nagyvárosi felnőtt népesség, a vizsgált paraméterek alapján, a társadalmilag nagyon erősen beágyazódott típusba sorolható. A következő típusba, a kiemelkedő rokoni támogatottsággal rendelkező csoportba a városi felnőttek $42 \%$-a tartozik. A harmadik típus, az erős társasági-egyesületi kapcsolódással jellemezhető, a városban valamivel nagyobb (32\%), mint a járás egészére vetítve, de így is csak minden harmadik nyíregyházi felnőttet lehet ebben a típusban említeni. A negyedik típus, a gyengén integrálódottak aránya Nyíregyházán $38 \%$.

A járás többi települését elemezve látható, hogy a legtöbben (52\%) a kiemelkedő rokoni támogatottsággal jellemezhető típusba sorolhatók. Viszont kiemelendő, hogy a gyengén integrálódottak aránya a járás többi településén $48 \%$, azaz minden második felnőttre gyenge társadalmi beágyazottság jellemző kapcsolatait tekintve. Az erős társasági-egyesületi kapcsolatokkal bíró típus jellemző a legritkábban (23\%) a járás kisebb településein.

A megkérdezetek kora illetve iskolai végzettsége jelentősen összefügg a mikrotársadalmi integráció típusaival, függetlenül a település típusától, azaz mind a nagyvárosra, mind a kisebb településekre jellemzö.

Társadalmilag nagyon erős beágyazódottsággal jellemezhető csoportok településtől függetlenül a férfiak, a fiatalok (18-34 évesek) illetve a magas iskolai végzettséggel rendelkezők. A kiemelkedő rokoni támogatottsággal jellemezhető csoportok közé tartoznak a nők, az idősek (60 éves és idősebb népesség) és az alacsony iskolai végzettségüek. Erős társasági-egyesületi kapcsolatokkal bírók jellemzően a járásban föleg a férfiak (Nyíregyházán nincs különbség a két nem között), a fiatalok és a magas iskolai végzettségüek. A gyengén integrálódók közé a 
nők, a 35-59 évesek és az alacsony iskolai végzettségüek sorolhatók, de nagy az aránya a járásban élő fiataloknak is ebben a csoportban.

A közösségi munka, a közösségfejlesztés, a közösségi tervezés hatékony módszerei lehetnek kis településeken, illetve kis közösségekben a társadalmi részvétel, a közösségi aktivitás generálására, fejlesztésére, közösségi akciók kidolgozására. A közösen tapasztalt és végigvitt aktivitások hozzájárulhatnak a személyes kapcsolati háló kiterjesztéséhez, a gyenge, híd-szerü kapcsolatokkal való feltöltéséhez, mely erősítheti a társadalmi integrációt és a társadalmi szolidaritás fokát.

\section{Felhasznált irodalom}

1. Angelusz R. - Tardos R. (1998): A kapcsolathálózati erőforrások átrendeződésének tendenciái a kilencvenes években. In: Kolosi T. - Tóth I.Gy. - Vukovich Gy. (szerk.): Társadalmi Riport, 1998.

2. Balogh E. - Fábián G. (2012): Támogató rendszerek, szociális problémák és segélyezés. In: Fábián G. - Patyán L. - Huszti É. (szerk): Életminőség Nyíregyházán 2008-2010. START Nonprofit Kft. Nyíregyháza. 2012. pp. 135-154.

3. Bourdieu, P. (1983) Gazdasági tőke, kulturális tőke, társadalmi tőke. In: Angelusz, R. (szerk.) (1999) A társadalmi rétegződés komponensei. Budapest: Új Mandátum Könyvkiadó. 156-177.

4. Coleman, J. S. (1988) Social Capital in the Creation of Human Capital. American Journal of Sociology, 94, 95-120.

5. Dávid B. - Huszti É. - Lukács Á. (2015). A társas kapcsolatok jelentősége a társadalmi integrációban. Kézirat

6. Fábián G. (1997): A természetes védőháló és müködésének néhány sajátossága Nyíregyházán. Esély 8 (3), 67-75.

7. Fábián G. - Patyán L. - Huszti É. (szerk): Életminőség Nyíregyházán 2008-2010. START Nonprofit Kft. Nyíregyháza. 2012.

8. Granovetter, M.S. (1973): The Strength of Weak Ties. American Journal of Sociology, Volume 78, Issue 6. p. 1360-1380.

9. Granovetter, M.S. (1974): Getting a Job. Study of Contacts and Careers. Cambridge: Harvard University Press

10. Granovetter, M. S. (1982) A gyenge kötések ereje. A hálózatelmélet felülvizsgálata. In: Angelusz, R. \& Tardos, R. (szerk.) (1991) Társadalmak rejtett hálózata. Budapest: Magyar Közvéleménykutató Intézet. 371-400.

11. Gyarmati A. (2009): Hogyan verjünk hidat az idősekhez? Az ötven év fölöttiek kommunikációs és kapcsolathálózatának néhány jellemzője. Információs Társadalom, 9. évf. 4. sz. www.epa.oszk.hu/01900/01963/.../infotars_2009_09_04_055-069.pdf

12. Huszti É. (2012): Társas kapcsolatok. Családi, rokoni, baráti kapcsolatok Nyíregyháza lakói körében 2008-2010. In: Fábián G. - Patyán L. - Huszti É. (szerk): Életminőség Nyíregyházán 2008-2010. START Nonprofit Kft. Nyíregyháza. pp. 155-176

13. Huszti-Patyán-Fábián (szerk.): Életminőség Nyíregyházán 2012. Acta Medicinae et Sociologica Vol.5.No.12-13. 2014

14. Huszti É. (2014): Társas kapcsolatok Nyíregyházán. In: Huszti-Patyán-Fábián (szerk.): Életminőség Nyíregyházán 2012. Acta Medicinae et Sociologica Vol.5.No.12-13. pp. 143-165.

15. Hüse L. (2015): A szubjektív egészségi állapot tényezői és azok változása Nyíregyházán és vonzáskörzetében. Acta Medicinae et Sociologica Vol. 6. No. 18-19: 96-120. 
16. Kolosi T. - Tóth I.Gy. (szerk.): Újratervezés. Életutak és alkalmazkodás a rendszerváltás évtizedeiben. Kutatási jelentés a „Háztartások életút vizsgálata” (HÉV) alapján. 2008. http://www.tarki.hu/hev/hev-1/ujratervezes-eletutak-es-alkalmazkodas-a-rendszervaltasevtizedeiben

17. Lin, N. (2008) A network theory of social capital. In: Castiglione, D., van Deth, J. W. \& Wolleb, G. (szerk.) The Handbook of Social Capital. Oxford: Oxford University Press. 50-69.

18. Malakucziné Póka M. (2015): A Nyíregyházai járás települési szerkezeti, demográfiai, háztartási jellemzői. Acta Medicinae et Sociologica Vol. 6. No. 18-19: 11-29.

19. Nyírcsák J. (1999): Természetes támogató-rendszerek Nyíregyházán. In: Lukácskó Zs.-Fábián G.-Fónai M. (szerk.): „Peremvidék” - szociális kutatások Szabolcs-Szatmár-Bereg megyében. Nyíregyháza-Salgótarján: DOTE Egészségügyi Főiskolai Kar - Salgótarjáni Népjóléti Képzési Központ, 1999.

20. Omnibusz, $2011 \quad \mathrm{http} / /$ www.academia.edu/1428370/TARKI_-_Omnibusz__Bar_egyre_tobb_a_baratunk_minden_otodik_felnottnek_nincs_baratja

21. Patyán L. (2015): A Nyíregyházi járásban élő idősek életkörülményei. Acta Medicinae et Sociologica Vol. 6. No. 18-19: 162-180.

22. Sik, E. (2012) A kapcsolati tőke szociológiája. Budapest: Eötvös Kiadó.

23. Szabó L., (2005) A társadalmi támaszt nyújtó személyes kapcsolatháló és a szubjektív életminőség összefüggései az egészséges és mozgáskorlátozott személyek körében. $\mathrm{PhD}$ értekezés. http://phd.lib.uni-corvinus.hu/95/

24. Szigeti F.-Fábián G.-Takács P. (2015): Az érzelmi jólléti mérése a Nyíregyházi járás településein. Acta Medicinae et Sociologica Vol. 6. No. 18-19: 145-161.

25. Takács P. - Fábián G. - Szigeti F. (2015): A Nyíregyházi Háztartáspanel életminőségi modellvizsgálatok legújabb eredményei, valamint az életminőség modell bővítésének lehetőségei a Rough Set Theory alkalmazásával címủ tanulmányt. Acta Medicinae et Sociologica Vol. 6. No. 18-19: 198-225.

26. Utasi Á. (2002): A bizalom hálója. Budapest, Új Mandátum Könyvkiadó.

27. Utasi Á. szerk. (2006): A szubjektív életminőség forrásai. Biztonság és kapcsolatok. MTA Politikai Tudományok Intézete, Budapest.

28. Utasi Á. (2008) Éltető Kapcsolatok - A kapcsolatok hatása a szubjektív életminőségre. Budapest: Új Mandátum Könyvkiadó.

29. Utasi Á. (2013): Kötelékben. Szolidaritás-hálók és közélet. Belvedere, Szeged, 2013.

\section{A szerző}

Huszti Éva Ph.D. szociológus, főiskolai docens

Debreceni Egyetem Egészségügyi Kar, 4400 Nyíregyháza, Sóstói u. 2-4. 